"A Natural History of the Animal Kingdom, being a Systematic and Popular Description of the Habits, Structure and Classification of Animals from the Lowest to the Highest Forms, arranged according to their Organization." London, 1856. 8 vo. pp. 818 , and 374 woodcuts (originally issued as a series of articles in Orr's "Circle of the Sciences," where it appeared in 28 parts, from 1854 to I855).

Elements of Entomolngy : an Outline of the Natural History and Classification of British Insects. London, 185̃7. 8vo. pp. 424. (Van Voorst.)

Sketch of the Genus Precilocoris, belonging to the Hemipterous Family Scutelleridee.

Entomological Society's Transactions, v. 1847-9, pp. 100-109.

Notice of some Hemipterous Insects from Boutan (in the Collection of the Hon.

East India Company), with Descriptions of the New Species. Entom. Soc. Trans.

v. 1847-1849, pp. 186-194.

A new Hemipterous Insect from Boutan (East Indies), forming the Type of a New Genus (1849). Entom. Soc. Trans. i. 1850-51, pp. 1-3.

Notice of some Hemiptera from Boutan (Hon. East India Company) [1849].

Entom. Soc. Trans. i. 1850-51, pp. 4-11.

Note on the British Species belonging to the genus Acanthosoma, Curt. Entom.

Soc. Trans. i. 1850-51, pp. 109-114.

Description of a new Hemipterous Insect forming the Type of a New Genus (Atelides centrolineatus). Annals and Mag. Nat. Hist. x. 1852, pp. 359 and 436.

Descriptions of some New Species of Hemipterous Insects belonging to the Tribe Scutata. Entom. Soc. Trans, ii. 1852-53, pp. 6-17.

Description of a New Species of the Genus Dinidor, belonging to the Hemiptera scutata. Entom. Soc. Trans. ii. 1852-53, pp. 18-19.

On the Feathers of Dinornis robustus, Owen, Ann. and Mag. Nat. Hist. xvi. 1865, pp. 66-69. Ann. Sci. Nat. iv. 1865 (Zool.), p. 292. Zool. Soc. Proc. 1865, pp. $26 \overline{5}-268$.

On the Occurrence of Tinnuneulus cenehris in Britain. Ann, and Mag. Nat. Hist. ii. 1868 , pp. $75-76$.

Translator of C. T. von Siebold's work on a true Parthenogenesis in Moths and Bees. 8vo. London, 1857.

Translator of Prof. 0. Heer's " Primæval World of Switzerland," in two vols. pp. 742 ; with 500 illustrations. (Longmans \& Co., 1876).

Translator of "Facts and Arguments for Darwin," by Fritz Müller. 8vo. pp. 144. London, 1869. (J. Murray.)

Author of the articles Rodentia, Chiroptera, Insectivora. Hymenoptera, Neuroptera, Diptera, Aphaniptera, Rhynchota, Orthoptera, Thysanura, Myriopoda, Arachnida, in Cassell's Natural History. 1882.

Translator of vol. v. of Humboldt's Cosmos, 1858. 8vo. pp. 500. (Bohn's Scientific Series.)

Translated the foreign articles for the "Chemical Gazette" (1852-59), for the "Philosophical Magazine," for the " Reader," and for the "Annals and Magazine of Natural History" (180̄2-90).

Numerous reviews and articles in the "Westminster Review."

Translator of Buchner's "Man, Past and Present," and Nitzsch's " Pterylography."

H. W.

\title{
SIR W. W. SMYTH, M.A., F.R.S.
}

Ir is with deep regret we record the death, from heart-disease, of Sir Warington W. Smyth, M.A., F.R.S., Foreign Secretary of the Geological Society of London; which occurred at his residence, 5 , Inverness Terrace, on Thursday, the 19th June. An Obituary Notice will be given next month. 


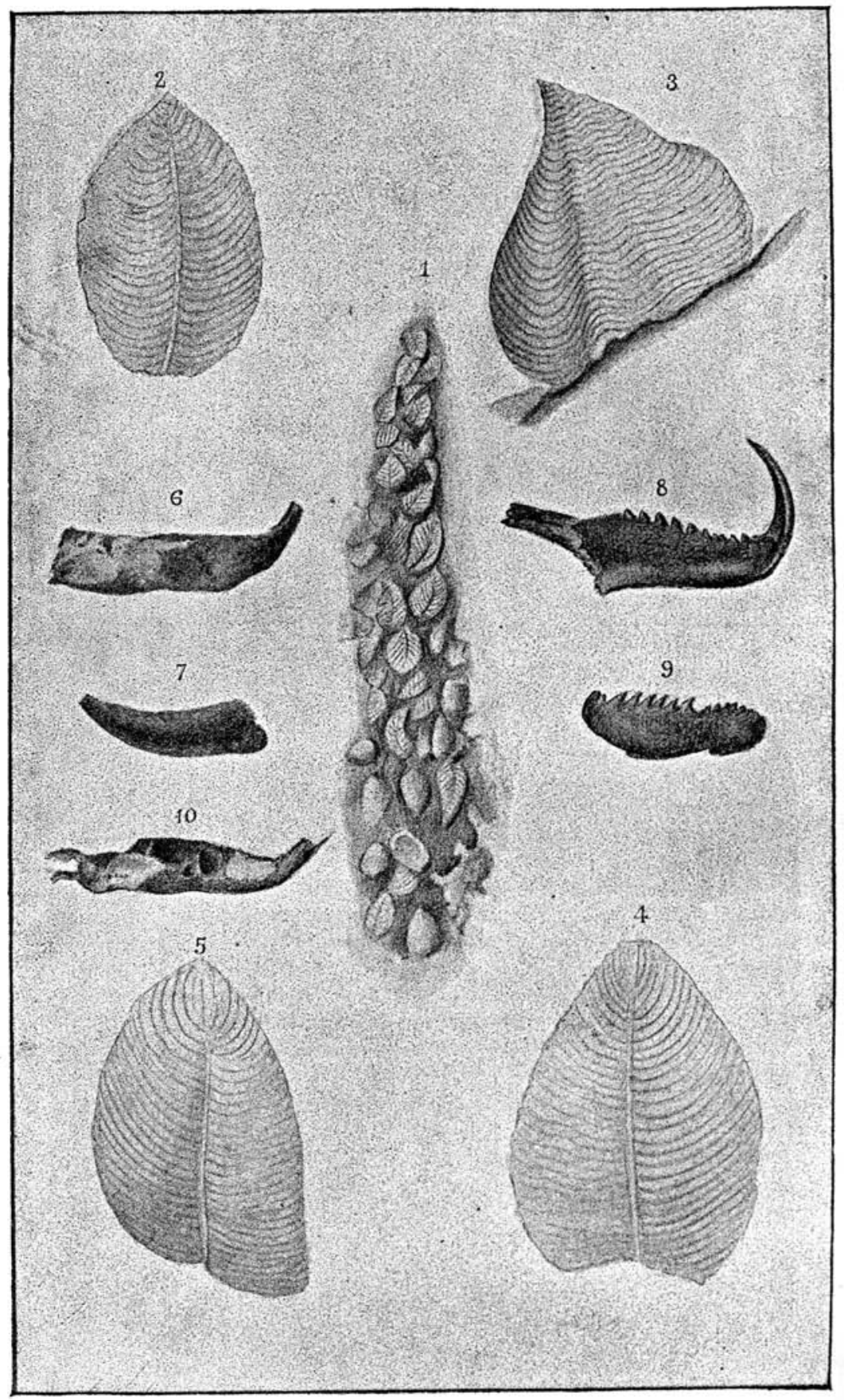

Turrilepas and Annelid Jawes: U. Silurian: New South Wales. 